\title{
Enhancing Skills of Critical Thinking by Using Learning Management Systems
}

\author{
Prof. Hamdy Ezz Elarab ${ }^{1}$, Mohamed Maddy ${ }^{2}$ \\ ${ }^{1}$ Professor of Instructional Technology, Member of Digital Design and Publishing Research Unit (DDPRU) \\ Faculty of Education, Tanta University, Egypt \\ ${ }^{2}$ Ph.D. in Instructional Technology, Faculty of Education-Tanta University, Classera Company
}

\begin{abstract}
Learning management systems (Moodle) are considered one of the most important learning systems in the world due to their technical and educational capabilities helping to upgrade the level of the educational process. That study aims at verifying the effectiveness of these capabilities on improving skills of critical thinking for teachers while using Moodle systems at designing and managing courses. Study sample was formed of(30) teachers at a prep school in (Kafr El-sheikh, Egypt). A card for evaluating skills of critical thinking of teachers was designed by using Moodle system. Results of the study proved a remarkable improvement in critical thinking skills for teachers via exchanging experience and knowledge during the design of courses using Moodle systems..
\end{abstract}

Keywords: Moodle systems, skills of critical thinking, learning management systems, LMS

\section{Introduction}

Systems of producing educational content have arisen as a result of an increase in their availability and great demand to open and distance learning online. Before having these systems, educational contents were presented either in the form of e-mails or web pages without needing for a real learning environment. That is why there was a necessity for creating a system gathering between the different shapes of learning systems on the internet. The term "learning environment" was used to express integrity and suitability of the system for all learners [1]. (argued that the term of content managing system can be synonymous with the term of systems of managing curricula, so both terms refer to those online implements which have many educational merits and techniques; things which ease designing and managing electronic content in the electronic learning environment[2]. (Rengarajan, 2001) confirmed that learning management systems control activities of the educational system such as managing virtual classes online and recording individual and collective skills of students, easy accessibility to the curricula and producing reports[3]

concerning noticing performance improvement of students. Moodle is seen as one of the digital learning management systems which help teachers provide an electronic educational environment[4]. (states that Moodle system can be used by individuals and organizations [5]. (referred that electronic learning by using Moodle system enhances students' abilities to participation, exchanging opinions and electronic dialogue[6]. summarizes Moodle's advantages: they are accessible programs controlled by Gun licence, providing possibility of synchronic and nonsynchronic interaction between students and each other in a hand, and between teachers and students on the other hand through chatting, e- mails or educational forums. As a matter of fact, thinking is a daily process which affects 
our planning for life's goals and decisions, so thinking helps us to handle what we can do and what we must do besides getting rid of doubts by selecting the proper probabilities resulting from researching in simple and complex information [7]. In many countries, critical thinking has become a basic goal of education seeking for improving students' levels. Moreover, critical thinking has become a slogan for many educationalists; the thing which led to many studies and researches concerning empowering skills of critical thinking to be included in curricula [8]. (Chen, 2003) sees that critical thinking is a series of self - directed and spontaneous processes which include using mental skills to accept or refuse a certain issue or delaying judging it for non-availability of information. [9] Justifies caring with critical thinking for the following reasons: it helps students to adapt to changes; it leads to deeper understanding for problems and challenges besides making students able to make suitable decisions which satisfy their needs.

\section{Methodology and Procedures}

The current research seek to verifying the effectiveness of designing electronic curricula by using learning management systems (Moodle) on improving prep teachers' skills of critical thinking by checking the following :

- Relationship between teachers' practice for skills of designing electronic curricula by using Moodle systems and skills of critical thinking.

- The effect of improving critical thinking skills on skills of designing electronic curricula.

- Role of Moodle systems in vocational development of teachers.

Thus, the research is so important because it provides a practical model for employing learning management systems in strengthening teachers' skills of critical thinking .Moodle was focused on as it is considered one of the famous world systems for managing electronic learning inside universal organization. During designing electronic curricula by using Moodle system controlled by certain educational criteria, skills of critical thinking were measured which are analysis, induction, evaluation, deduction and reasoning. The researcher held sessions to test skills of critical thinking methodologically on the research sample which included (30) teachers at a prep school in (Kafr El-sheikh in Egypt). Those teachers were trained to practice Moodle systems for designing curricula and skills of critical thinking. Sessions were held from July 2019 until December 2019) at the average of( 2-3 sessions a week. To verify research results, the next assumption was formed "there are no differences with statistical significance at level $(0.05)$ between the pre /post test at the favor of the post test ".

\section{Results}

After doing T-test, the research showed a statistical correlation between designing electronic curricula by Moodle systems and teachers' skills of critical thinking as the following table shows:

Table (1) statistical significant differences between means of performance grades of critical thinking and learning management in the pre-post tests of the experimental group

\begin{tabular}{|c|c|c|c|c|c|}
\hline Group & Means & $\begin{array}{c}\text { Standard } \\
\text { deviation }\end{array}$ & $\begin{array}{c}\text { Degree } \\
\text { of } \\
\text { freedom }\end{array}$ & $\begin{array}{c}\mathrm{T} \\
\text { value }\end{array}$ & Significant \\
\hline Pre & 2.9 & 1.09 & 14 & 10.3 & 0.05 \\
\hline post & 27.8 & 1.6 & 14 & \\
\hline
\end{tabular}

The previous table shows a difference between the pre and post tests of the experimental group (Moodle) at the favor of the post test. Mean of the pre - test grades was 2,933 which is fewer than the post test (27.8). That difference is a statically significant because calculated value of "T" was (10.3) which is greater than table value of " $\mathrm{T}$ " which is (0.05) . That proves the acceptance of the assumption and rejecting the other one.

\section{Discussion}

By analyzing the previous results, we notice the following:

- Availability of sharing Moodle systems' tools.

- Using those tools led to an effective synchronic participation which resulted in exchanging experience regarding problems teachers face during designing curricula.

- Discussions between teachers tackled with required skills for designing electronic curricula.

- Change at critical thinking skills for teachers got along with the previous studies in that field which concluded that sharing between peers has a lot of benefits such as exchanging knowledge and experience besides evaluating students; the thing which leads to upgrading production and skills.

- Mutual performance of teachers while designing curricula has contributed to build collective learning community.

- Efficiency of Moodle sharing tools led to increasing cooperation between teachers.

\section{Recommendation}

It is necessary to train teachers to use Moodle systems.

- Caring with activating skills of evaluating peers for teachers during the process of vocational preparation.

- It is necessary for teachers to have skills of designing curricula via electronic learning management systems besides applying these skills at educational organization to be a tool for evaluating teachers. 


\section{Conclusion}

Moodle system is considered one of the most important electronic learning systems nowadays as it depends on developmental method in all aspects inside educational organization, whether they are schools or universities. It is necessary to put a long term strategy which is adaptable to educational criteria to achieve goals of Moodle system.

\section{References}

[1] Chen, F. \&. (2003). Effect of nursing literature reading course on promoting critical thinking in towyear nursing program students. Journal of Nursing Research, 11 (2).

[2] Dabbagh, N. (2004). Pushing the envelope: Designing authentic learning activities using course management systems. In Proceedings of world conference on e-learning in corporate, government, healthcare, and higher education 2004.

[3] Turky, M., Soliman, N. (2020). Developing autoDidactic (Self-Learning) Skills by Using Social Networking. International Journal of Instructional Technology and Educational Studies, 1(1), 16-19. doi: 10.21608/ihites.2020.28705.1004

[4] Kyei-Blankson,. (2016). Adopting and Implementing an E-Learning System for Teaching and Learning in Saudi Public K-12 Schools: The Benefits, Challenges, and Concerns. World Journal of Educational Research ISSN 2375-9771.

[5] Rengarajan,.(2001). LCMS and LMS Taking advantage of Tight Integration.

[6] Ismail (2009). E-learning from the app to professionalism and quality. Cairo: The World of Books.

[7] Turky, M., (2017). "Enhancing Meta-Cognition Skills by Using Reflective E-Portfolio", Digital Design and publish research unit (DDPRU) Faculty of Education, Tanta University, Egypt https://files.eric.ed.gov/fulltext/ED574779.pdf, .

[8] Atemisi. (2007). Teachers guide to open source education management system. Palestine, Polytechnic University.

[9] Sadiq (2008). A suggested program in e-learning using free open source software and its effect on developing design skills and production of e-math lessons for teacher students. Journal of the Faculty of Education in Mansoura, Faculty of Education, Mansoura University, No. 66, Part Two. 